\title{
Double Whammy: Implicit Subsidies and the Great Financial Crisis
}

\author{
Edward Kane ${ }^{\# *}$
}

\section{Working Paper No. 81}

\author{
September 2018
}

\begin{abstract}
This paper concerns itself with the joint effect of implicit subsidies that are built into the US housing-finance system and financial safety net. These subsidies are implicit because they are channeled through the regulatory, supervisory, and tax systems in hard-to-observe ways. In the last two economic booms, the stealthy way banks have pursued these subsidies allowed hidden leverage and arcane loss exposures to build up to a disastrous degree.

When lenders' safety-net support was finally tested by creditor runs, the struggle to reallocate losses and loss exposures away from the banks that had concealed them pushed the world's financial system into open crisis. Post-crisis regulatory reforms seem to have blunted the force of these subsidies, but the instruments assigned to this task are too weak to work for long. With the connivance of regulators, US megabanks are already re-establishing their ability to use dividends and stock buybacks to rebuild their leverage back to dangerous levels.

Meantime a number of European megabanks (exemplified by Deutsche Bank) have remained in a zombie or near-zombie condition throughout the last decade. In the coming years, these banks' perilous condition and the possibility of extending safety-net coverage to

\footnotetext{
Boston College

The research reported in this paper is excerpted from a partially written book whose preparation is being supported by a grant from the Institute for New Economic Thinking. Robert Dickler, Thomas Ferguson, and Larry Wall have offered valuable comments on this work as it has been unfolding.
} 
support subsidized loans for bankrupt students, pension funds, and state and local entities could easily trigger another crisis.

Besides trying to avoid future crises and directing bailouts when a crisis occurs, top regulators seem to believe that an important part of their job is to convince taxpayers that the next crash can be contained within the financial sector and won't be allowed to hurt ordinary citizens in the ways that previous crises have. This paper seeks to convince readers that, until the law begins to hold individual bankers civilly and criminally responsible for using the safety net to enrich themselves by recklessly putting their banks' survival at risk, these rosy claims are bullsh*t.

JEL Codes: E02, E32, E42, E52, E58

Key words: Too big to fail, financial safety, financial reform, financial crises, implicit subsidies, political economy 
Double whammy has two meanings. One derives directly from "wham," as in "whambam," which is a way of approximating the sounds made by a solid one-two punch. The second meaning comes from its use in the comic strip L'il Abner, where it meant a devastating curse that a hag named Nightmare Alice would cast on other characters from time to time. Both meanings are relevant here.

The word subsidy covers any kind of direct or indirect payment, concession, or privilege granted by a government to private firms, households, or lesser governmental units. A word that carries so many meanings calls out for a modifier. An implicit subsidy is one that is hard to document because it is transmitted in kind or through favorable pricing and tax breaks rather than in the coin of the realm. This paper concerns itself with the joint impact of implicit subsidies that are built into the US housing-finance system and financial safety net. These subsidies are implicit because they are channeled through the regulatory, supervisory, and tax systems in hard-to-observe ways. In the last two economic booms, their stealthiness has allowed these subsidies to build up so much malignant force that, when the extent of their political support was tested by a creditor run, the losses their stealthiness concealed pushed the nation's financial system into an open crisis.

What an economist calls a crisis occurs when bad luck impacts a large industry whose managers have made its member institutions vulnerable to this amount and type of misfortune. In one way or another, most banking crises are triggered by sudden falls in the price of key assets. The twin subsidies featured in this paper encourage banks to make underpriced loans to housing-related sectors of the economy, particularly those that make or market residential housing or influence its affordability. The ostensible public purposes of subsidies to housing are to improve fairness in society by encouraging home ownership and assuring healthful 
neighborhoods and adequate housing for low-income households (see Hock-Smit and Diamond, 2003). Routing these subsidies through mortgage lenders suggests that a deeper purpose may be to subsidize realtors, builders, landlords, and mortgage lenders. A major part of the safety-net subsidy is the quid US bankers receive for pricing mortgage loans favorably. It consists of regulatory and supervisory indulgences that neglect the implicit loss exposures that subsidized mortgages and innovative instruments pass onto the safety net by the highly leveraged way these positions are financed.

Because both subsidies are implicit, they currently leave no paper trail. Neither subsidy is explicitly accounted for in bank, borrower, or government financial statements. Authorities could (if they wanted) track the effect of these subsidies in reducing the default premia and liquidity premia imbedded in the interest rates offered to mortgage borrowers by developing a way to approximate the unobservable interest rate that different types of borrowers would have had to pay in the absence of the subsidy. Today, an official value for the consolidated housingfinance subsidy is not even tracked loosely, while the value of countervailing supervisory concessions that regulators and supervisors transmit to mortgage lenders through the safety net is not booked anywhere either.

\section{Modeling the Sequence of Events Observed in a Subsidy-Induced Crisis}

My narrative models of crisis generation locate efforts to preserve and extend rentseeking opportunities for different-sized banks at the center of the process. I contend that successful efforts to secure these subsidies owe a large debt to investors' willingness to rely upon the supervisory and justice systems rather than do their own due diligence. This left them 
vulnerable to these systems' overbearing tolerance for self-serving financial-industry bullsh*t. ${ }^{1}$

Even today, in the press and in history books, policymakers and industry-captured economists

and accountants consistently misframe regulatory and supervisory incentive problems and

overstate the strength of potential justice-system remedies.

During the buildup to the Great Financial Crisis, the most important misframing was to deliberately misrepresent the ways that tail risks and the costs, benefits, and distribution of government tail-risk protections move through megabank balance sheets. A close second was to misrepresent the purpose and productivity of innovations that cleverly circumvented and eventually unmasked the futility of poorly conceived forms of regulation and supervision by generating de facto losses and transmitting these losses from bank to bank and country to country. $^{2}$

\section{Why Wasn't Somebody Watching the Back Door?}

Regulation is best understood as a dynamic game of action and response, in which either regulators or regulatees may make a move at any time. In this game, regulatees tend to make more moves than regulators do. Moreover, regulatee moves tend to be faster and less predictable, and to have less-transparent consequences than those that regulators make.

\footnotetext{
${ }^{1}$ According to Frankfurt (2005), bullshit differs from lying in that the bullshitter ignores the truth instead of acknowledging and then subverting it. Among my childhood friends, that was our definition of horseshit, to which the bullshitter adds an intention for his horseshit to be taken seriously. For example, Rep. Blaine Luetremeyer (Missouri) -who tops the list of House recipients of bank support in the morerecent election cycle-repeatedly asserts that small banks "were not part of the problem" that caused the Great Financial Crisis and that rolling back the Dodd-Frank Act would greatly improve customer access to credit and lower its cost (Kline, 2018).

${ }^{2}$ Since leaving office, Fed Chairman Alan Greenspan has expressed regret for having produced this particular kind of misinformation.
} 
This is because the essence of banking is deal making. In modern times, banking crises have occurred when managers pursued concentrated tail risks that made their institutions increasingly vulnerable, but generated a series of substantial and long-lasting safety-net subsidies until things finally went south.

Such subsidies can prove long-lasting because the regulatory cultures of almost every country in the world today embrace --in one form or another-- three strategic elements:

1. Politically-Directed Subsidies to Selected Borrowers: The policy framework either explicitly requires - or implicitly rewards - institutions for making credit available to favored classes of borrowers at a subsidized interest rate. In recent crises, subsidized loans to homeowners played this role. However, the next crisis may feature loans to current and former students, pension funds, and state and local entities; ${ }^{3}$

2. Subsidies to Bank Risk-Taking: The policy framework commits government officials to offer on subsidized terms explicit and/or implicit (i.e., conjectural) guarantees of repayment to banks' depositors and other kinds of counterparties engaging in complex forms of bank deal making;

3. Defective Monitoring and Control of the Subsidies: The contracting and accounting frameworks used by banks and government officials fail to make anyone directly accountable for reporting or controlling the size of these subsidies in a conscientious or timely fashion.

Taken together, the first two elements of the subsidization strategy invite commercial and investment banks to use the safety net to extract wealth surreptitiously from taxpayers. To keep

\footnotetext{
${ }^{3}$ To defend these subsidies politically, beneficiaries (such as realtors, builders, landlords, and lenders) are apt to earmark a small portion of their subsidies for "community groups" who profess to believe sincerely in the social benefits of subsidizing the loans in question.
} 
subsidy-generating leverage high, the bulk of the subsidies banks receive are promptly paid out to top managers and to shareholders in the form of dividends and share repurchases. The rest is shifted forward and backward: mostly to large creditors and politically favored borrowers. Favored borrowers are primarily blocs of voters (such as would-be homeowners) regularly courted by candidates for political office and traditional sources of outsized campaign support (such as bankers, builders, and realtors). Ferguson, Jorgensen, and Chen (2017) define a comprehensive concept of "political money" that captures a number of indirect and subtle ways that bankers (especially) put money into a politician's pocket or election campaign. The direct ways include director's and speaking fees, book contracts, jobs for family members, and stock tips. Indirect channels comprise laundering donations through law firms, charitable foundations, think tanks, and public-relations firms.

The third piece of the framework minimizes regulators' exposure to blame when things go wrong. Gaps in the reporting system make it all but impossible for outsiders -particularly the press-- to hold supervisors culpable for violating their ethical duties. These gaps prevent outsiders from understanding --let alone monitoring-- the true costs and risks generated by the first two strategies. Few politicians and regulators want to subject the intersectoral flow of net regulatory benefits to informed and timely debate. This weakness in accountability exists because the press is often content with regurgitating the content of agency press releases and accounting systems do not report the value of regulatory benefits as a separate item for banks and other parties that receive them.

In modern accounting systems, the capitalized value of regulatory subsidies is treated instead as an intangible source of value that, if booked at all (as it usually is in acquisitions), is not differentiated from other elements of what is called an acquired bank's "franchise value." Of 
course, some of the subsidy is offset by tangible losses that politically influenced loans eventually force onto bank balance sheets and income statements. But in principle, a tangible reserve for expected losses ought to be set up (and is scheduled to be under FASB's new lossreserve standards) as part of the process of making either a subsidized or risky loan.

Although officials resist the idea, creating an enforceable obligation for regulators to estimate the ebb and flow of the dual subsidies in transparent and reproducible ways would be a useful first step in getting them under control. This would make it easier for external watchdog organizations in the private sector to force authorities to explain whether and how these subsidies benefit taxpayers.

\section{Why Does It Matter Whether the Subsidies Are or Are Not Booked Explicitly?}

What the press characterizes as a "financial crisis" I would describe more colorfully as a game of chicken between supervisors and central banks on the one hand and formally uninsured institutions and creditors on the other. At root, it is a messy scramble for help. A powerful horde of loss-making institutions keeps it going until, using political force, they manage to compel the rest of society to cover the bills they owe for making bad loans and investments. In US mortgage markets, longstanding systems for subsidizing poorly underwritten loans to builders and overleveraged households assign potential losses initially to the lending institutions, but these firms cover these losses with safety-net guarantees that pass their worst loss exposures onto national safety nets.

Booking loans at par when they are made to iffy borrowers on subsidized terms implies a projected time path of subsequent cash flows from these mortgages that understates the probable rate of future defaults and overstates the liquidity that these instruments transmit to mortgage 
lenders. These false projections open up a gap between the book value and market value of highly subsidized mortgages. The adverse effects of this gap emerge slowly as a series of ex post accounting losses at lending banks, but only if the banks that originate the loans continue to hold them.

To see how this works, let's assume that (if not for the housing-finance subsidy) the default and liquidity premia in a loan portfolio accruing 6 percent actually called for a market interest rate of 7 percent. Booking these loans at par overstates their likely returns and, on average, the passage of time is bound to reveal this.

Savvy bankers should understand this and devise ways of shedding these loss exposures. This is where securitizations come in.

\section{How Securitizations Undermine Capital-Requirement Subsidy Control}

The seeds of crisis are sown in good times. Being allowed to under-reserve for writedowns that can be expected to occur over the life of long-term loans intensifies safety-net subsidies, and does so all the more if securitization lends a hand. Especially when aided by bullsh*t representations and warranties, securitization offered mortgage lenders a loophole opportunity to circumvent virtually all of the regulatory burden associated with the already-low capital requirements that the politics of the housing subsidy had settled on housing-related assets.

When housing prices are booming, securitizing and re-securitizing pools of loans rather than keeping them on balance sheet allows a lender to liquefy its share of both subsidies immediately and pass the funds through to its major stakeholders. But the overleveraging and overvaluing of the lender's portfolio of mortgage loans that securitization encourages cynically moves the entry points for future crisis into formally unguaranteed part of the banking system. 
The process of using corporate subsidiaries to securitize subsidized mortgages may be visualized as setting loose the equivalent of a colony of termites to feed slowly on the asset and net-worth accounts posted on the conventional balance sheets of whoever books these loans at par. Over time, the net worth of more and more mortgage holders hollows out as the cumulative damage from misvalued mortgage loans becomes increasingly harder to hide. Before this starts to happen, most of the benefits of the initial lenders' implicit subsidy for making overleveraged loans will have been taken out of the banking system. Safety-net subsidies are distributed more or less as they accrue to shareholders (through dividends and share buybacks) and to top managements as performance bonuses. Moreover, any manager who wants to pursue the safetynet subsidy to the max can place further high-risk bets by funding their firm's mortgage holdings with short-term liabilities. When mortgage holders do this during a prolonged boom, the losses hidden outside of institutions' financial statements become ever more extensive as the funding interest rates they have to pay soar beyond the rates they earn on their mortgage portfolio.

One of the first things any economist learns is that taxes and subsidies are shifted to some degree forward to consumers and backwards to parties located in other parts of the supply chain. In periods of macroeconomic expansion, the process of shifting generous mortgage-rate and safety-net subsidies into house prices helps to push housing prices upward, eventually to unsustainable levels. At lending banks, a period of rising house prices inevitably triggers relaxed credit standards for qualifying would-be homebuyers for a mortgage loan. But when house prices level off or begin to fall, lenders' standards have to tighten again and the loans written during the last years of the boom are seen to be overpriced and evidence a loss in value.

In hopes of preventing these anticipatable losses from boring a huge hole in their net worth and to cash in some of their safety-net subsidies, bankers sold pools of mortgage loans at 
or near par to any securitizer who would take them. This includes sales to third parties and to sister subsidiaries and affiliates as well. Sales of new loans provided a way both to liquefy their claim to housing and safety-net subsidies and to move potential losses off their banks' accounting balance sheets. Most of these sales were incomplete in the sense that securitizers in the investment-banking industry were interested in buying mortgages whose quality was high enough to allow them to be absorbed into collateralized debt obligations (CDOs) for which -by stressing the wide range of geographic locations of the borrowers in the pool-- they were able to claim a triple-A rating. This kind of pooling left banks holding the residual low-rated tranches of numerous CDOs. During the crisis, these became worthless.

Sales could not prevent the emerging shortfall in payments from unqualified borrowers from hurting the banks' positions and those of its subsidiaries and affiliates. Once housing prices stopped rising, managers of short-funded pools of low-quality mortgages found it hard to roll over their financing. Foreshadowing the onset of a full-fledged crisis in the US and Europe, the rollover risk encountered by short-funded mortgage-backed securitization vehicles became more and more concerning from July 2007 on.

\section{Dialectics of This Explosive Policy Mix}

As a boom in housing prices proceeds, the cost of financing the subsidies grows and saddles more and more households with housing-related debt that is potentially more difficult to service than they realize. To keep this debt from restraining household consumption and to keep the subsidies flowing, monetary policymakers feel political pressure to follow expansive policies that support employment, wages, and credit growth.

Table 1 models --in words rather than in equations-- the life-cycle of a subsidy-induced crisis. The narrative shows that the subsidy-driven boom in housing and the rising implicit cost 
of safety-net coverage do not start to be challenged until doubts about the government's ability to manage the growing safety-net costs lead large creditors to engage in "silent runs" from bankingorganization debt. These runs are called "silent" because - unlike runs initiated by retail depositors - they create little or no concurrent publicity. Still, by firmly testing banks' ability to roll over their liabilities, they force asset sales and the issuance of new higher-priced liabilities. These transactions begin to surface at least some of the losses imbedded in the financial system's mortgage portfolio and net-worth.

The sequence of crisis events observed in most countries conform to the pattern of crisis generation and response shown in Table 2, generally stalling short of full cleanup at stage 4B or 5A. The 2007-08 breakdown of arrangements for financing structured securitizations of US mortgages in the US and Europe show this pattern, as did the 1997-1998 banking crises that roiled through Latin America, Japan, Korea, the Philippines, Malaysia, Indonesia, Thailand, and Russia. $^{4}$

\section{The Pre-Crisis Stages of Aggressive Subsidy Pursuit and Regulatory and Supervisory}

\section{Forbearance}

Across the world, authorities confront asset-price declines in more or less the same ways. Although German, British, and American authorities showed a willingness to close smaller institutions, they also showed that, when it comes to a megabank, politicians are reluctant (if not genuinely afraid) to move beyond the stage of stopgap partial recapitalization stage (stage 4A). As long as the near-hopelessness of an institution's situation can be covered up, outsiders cannot easily distinguish a wave of financial-institution insolvencies from a transitory shortage of

\footnotetext{
${ }^{4}$ For detailed listings and analyses of late $-20^{\text {th }}$ century crises, see Caprio and Klingebiel (1999), Honohan and Klingebiel (2000), and Beim (2001).
} 
aggregate liquidity. In either circumstance, what can be immediately observed is that a group of economically significant firms find it exceedingly difficult to roll over maturing debt on profitable terms. It is a culturally accepted first-response practice for central bankers and other regulators to provide liquidity to distressed institutions to buy time for supervisory staff members to investigate the extent to which irreparable insolvencies might underlie the distress. This bullsh*t time-buying strategy is supported by three exculpatory norms whose ethical force intensifies in times of political, market, or institutional turmoil: (1) a mercy norm; (2) a nationalistic norm; and (3) a non-escalation norm.

The mercy norm holds that it is bad policy and unacceptably cruel behavior for regulators to abandon the employees, creditors, and stockholders of institutions they oversee before they can convincingly establish whether the distress is too fundamental to be remedied by supervisory forbearance or subsidized loans. This norm gives regulators the discretion (if not the duty) to alleviate the initial pains of any client institution that experiences a silent run. A related norm supports a preference for completely rescuing the creditors of institutions that seem difficult to nationalize or unwind. To illustrate the sway of both norms, we need only cite the huge amount of relatively low-cost loans that the Federal Home Loan Bank System provided the hopelessly insolvent Countrywide Financial Corporation prior to its 2008 acquisition by BankAmerica.

The nationalistic norm presupposes that regulators should help domestic institutions and marketmakers to cope with foreign competition. In practice, this norm is reinforced by community resistance to foreign control of national credit decisions and by lobbying pressure from the politically favored sectors that suspect that foreign banks will not serve their interests very well. The operation of this norm can be illustrated by the Fed's successful efforts in 2008 to dissuade Deutschebank from competing with Morgan for the insolvent Bear Stearns franchise. 
The non-escalation norm allows authorities to lend on subsidized terms to distressed institutions and even to operate insolvent firms (such as Fannie Mae, and Freddie Mac) as temporarily nationalized institutions. To succeed in this officials had to popularize the view that there was little else they could do without inviting a national or global financial disaster. In invoking this norm, instead of putting Congress on the hook by publicly asking for the power to haircut creditors and openly recapitalize insolvent institutions, officials chose to spread fear. This forced them to argue that, without a large injection of subsidized funds, market forces would do terrible things: set prices for troubled assets that are unreasonably low, set prices for private credit to institutions that hold troubled assets that are unreasonably high, and transmit these price pressures to strong and healthy institutions in ways that would throw them into turmoil, too. Because regulators didn't really care whether these scary arguments were true, they qualify as bullsh*t.

Though customary, it is politically and economically dangerous for government officials to make these exaggerated claims and to deny the increasingly transparent flow of subsidies that partial recapitalization entails. When and if an official is discovered to have been misrepresenting the need for and extent of the anti-egalitarian redistribution of wealth that bailouts entail, he or she faces the likelihood of being made a bullsh*t scapegoat for the mess as a whole. For high-ranking regulators to want to keep churning out increasingly visible safety-net subsidies, two conditions must hold. First, they must be able to control the flow of information, so as to keep taxpayers and the press from convincingly assessing either the magnitude of the implicit capital transfer or the anti-egalitarian character of the subsidization scheme. Second, officials' commitment to these policies must be continually nourished by praise and other forms 
of tribute from the bankers, borrowers, and investors whose losses are being shifted to lessinfluential parties.

Authorities are reluctant to undertake a full recapitalization until hidden losses make themselves felt as irrepressible popular pressure. ${ }^{5}$ The longer the game goes on, the greater the risk that the reputations of incoming policymakers and the particular politicians that appoint them will be saddled unfairly with the sins of their predecessors. Although it is unwise to draw inferences from a small sample, the U.S. savings-and-loan mess and various Argentine crises cast some light on how unfairly costs are apt to be allocated during the final stages in the life cycle of a subsidy-induced crisis.

\section{Global Implications of the Forbearance Process}

In any country, the politics of crisis management favor whichever classes of bank stakeholders have the most to lose. As a result of stakeholders' differential ability to influence policy, the world has experienced a series of rolling and incompletely resolved crises that have kept most nations from approaching the vanishing point. These developments should sound at least three alarms. First, the frequency, severity, and geographic extent of banking crises convincingly demonstrate that, around the world, many institutions found it reasonable to book potentially ruinous risks. Looking at the period 1977-1995, Caprio and Klingebiel (1996) cite 58 countries in which the net worth of the banking system was almost entirely eliminated.

Extending the time period to 1970-2007, Laeven and Valencia (2008) found 42 severe (i.e., "systemic") banking crises from 37 countries and their paper examines the different ways that policymakers chose to deal with them. Second, in country after country, domestic (and

\footnotetext{
${ }^{5}$ Even when Congress finally granted bailout authority, it was neither characterized nor used as an instrument for assigning losses to uninsured creditors, which is the essence of a proper recapitalization.
} 
sometimes foreign) taxpayers have been billed to bail out bank stockholders, creditors (including depositors), and deposit-insurance funds (Demirgüç-Kunt, Kane, and Laeven, 2016). Third, the size and distribution of bailout costs is distressing. Honohan and Klingebiel (2003) confirm that, in modern crises, taxpayers' bill for making good on implicit and explicit guarantees typically ran between 1 and 10 percent of GDP. The size of these bailouts establishes that, at least in crisis countries, banks managed to put large bets on the table and were able to shift a substantial amount of the downside of these bets to taxpayers. Sometimes, but by no means always, authorities were eventually blamed for the size of the bills taxpayers were asked to pay. But officials hate to be blamed for anything. They make it hard for outsiders to establish definitively when supervisors recognized systemic problems and whether and how long they may have willfully shirked their obligations to expose loss-causing patterns of risk-taking in their regulatory domain and to take meaningful steps to control them. The ability to hide what they knew and when they knew it gives supervisors political cover for losses that result from their reluctance to address major bank insolvencies until the taxpayers' position deteriorated disastrously.

Whether supervisory mistakes are likely to be identified or not, in the midst of financial turmoil, industry lobbying pressure and weaknesses in ethical controls on the job performance of government regulators responsible for protecting the safety and soundness of financial institutions encourage regulatory forbearance. The high cost of modern crises indicates that the willingness of safety-net officials to expand taxpayer exposures to risks from the safety net greatly exceeds that of large-denomination creditors. Although institutional mechanisms for financing safety-net loans and guarantees differ across countries, information blockages and 
incentive conflict in government policymaking impede the fair and timely treatment of financial crises everywhere.

The appropriate policy response to crisis pressures depends on the nature of the policy contradictions that occasioned the crisis. A perennial issue is to assess the potential insolvency of troubled institutions and to determine how rapidly their net worth is being undermined by falling prices on the subsidized loans that created the crisis. Asset-price meltdowns are most likely to occur when incentives for over-lending by domestic and offshore institutions confront a national policy regime that offers incentives for over-borrowing at domestic households and firms. In such cases, downward pressure on asset prices is apt to generate insolvency and a crisis-intensifying flight from claims issued by the overleveraged borrowers to overleveraged lenders.

Although the mercy norm makes it conventional for central bankers to pretend that the silent runs that triggered either the GFC or other crises are driven by a shortage of aggregate "liquidity," creditor runs are usually driven by concerns about an institution's solvency. By the time a full-fledged crisis emerges, central-bank forbearance will have accommodated overspending in the favored-borrower sector for many years and probably also financed a long run of current-account deficits. In a system of flexible exchange rates, central bankers can prolong a payments deficit by letting the country's currency decline and/or by drawing down the country's foreign-exchange reserves and foreign lines of credit. In this kind of slow consumption-driven currency devaluation, the need to rebuild the central banks' currency reserves may never seem urgent. If it does seem urgent, authorities can shrink the currentaccount deficit in two complementary ways: (1) by allowing the exchange rate to decline even further and (2) by tightening their mix of fiscal and monetary policies. 
But when a money-center country is experiencing a crisis, this prescription is unattractive. Either policy would impose a sizeable opportunity loss on foreign and domestic holders of the country's financial assets. The currency-adjustment half of this strategy would put inflationary pressure on domestic prices. To pile these developments on top of the tight-money half of the prescription would induce a decline in aggregate economic demand, whose effects would reduce the real value of a country's financial assets in general and the net worth of its financial system in particular. This could further undermine asset values by raising prospective rates of default and delinquency on troubled assets. Still, in crisis circumstances, it is politically impossible for authorities to ignore the effects that macroeconomic policy adjustments have on safety-net loss exposures.

Demirgüç-Kunt and Huizenga (2010) show that, in a crisis, governments have to worry about their ability to raise the fiscal resources necessary to save their largest banks. Even in the US, it seems clear that fiscal-policy response to the Great Financial Crisis would have been much larger if authorities had not had to worry about maintaining the fiscal flexibility to back up the surge in the value of their implicit guarantees the GFC had caused.

In a financial center country, authorities face a Three-Way Policy Dilemma about how to control a silent run:

1. Choice One: Try to finance the runs with minimal adjustment in the loss-causing parts of the policy mix. We may characterize this strategy as deliberately disinformational. Authorities may temporarily nationalize one or more insolvent institutions and deny that many other zombies exist. They may or may not soften the potential decline in their exchange rate by tightening fiscal policy, establishing swap 
arrangements, drawing down reserves, or borrowing from private and official foreign sources.

2. Choice Two: Rebalance the policy mix to make it more sustainable, but only with respect to a narrowly defined window of time (e.g., until after one or a few more elections). Authorities may resolve or strengthen some of the weakest zombie institutions and may also try to increase monetary growth. We may describe this strategy as "partial recapitalization."

3. Choice Three (unlikely to be chosen unless prior efforts to use one or both of the other strategies have failed): Confront and eliminate the most obvious contradictions in the policy mix. The new policy regime should aim for a full cleanup of insolvent institutions and to establish a more incentive-compatible supervisory system going forward. The prime examples of this are Iceland in 2008 and the handling of the S\&L mess by the US in the early 1990s.

In crisis circumstances, the chief aim of policymakers is rescue. Politicians are strongly tempted to reflate demand and to strengthen the credibility of safety-net guarantees, without doing much to resolve the incentive distortions that widespread insolvency creates (DemirgüçKunt, Kane, and Laeven, 2016). In 2008, US regulators went initially with Choice Two, while European regulators opted for Choice One. The S\&L Mess had taught regulators in the US something that European regulators have yet to learn. Although it is dangerous to acknowledge and resolve corporate and financial-institution insolvencies in the midst of a national recession, leaving insolvencies unresolved can be even worse. Financial-institution and corporate insolvencies foster further mis-investment and enhance the likelihood that a still-deeper crisis 
will emerge down the line. Not having learned this lesson firsthand, European banking officials are still in denial about the dangers posed by zombie megabanks. Figure 1 provides day-by-day estimates of the subsidy being received by one of Europe's largest zombie megabanks since late 2013. Table 4 provides disturbing evidence about the current vulnerability of a number of others.

\section{The Dodd-Frank Act Exemplifies Choice Two}

Ferguson and Johnson (2009) provide an extensive and insightful analysis of the associated regulatory failures that the DFA was "intended" to correct. Aikman, Bridges, Kashyap, and Siegert (2018) document the build-up of household leverage and banking risks in advance of the 2008-09 crisis and provide evidence that post-crisis reforms could not (if they were in place prior to the crisis) have done much to stop this build-up.

Financial-institution lobbyists' explanations of the factors that led to the GFC are much simpler than either of these analyses. Their presentations begin with the bullsh*t claim that "our

guys" definitely didn't cause the crisis and usually grant that the true cause might have been one or more of the following items:

a. Excessive statutory deregulation of the financial sector

b. Dishonest accounting

c. Rent-seeking or incompetent executives in other sectors of the industry

d. Dishonest credit-rating firms

e. Defective systems of housing finance

f. Overexpansion and misregulation of derivatives transactions

g. Mistakes in monetary policy. 
Half-true lobbyist bullsh*t in, assured statutory bullsh*t out. I believe that the DoddFrank Act is best understood as a collection of policy measures designed to weave its way respectfully through these seven alternative theories of the crisis to incorporate a (sometimes lame) treatment of the forces featured in each of them.

What I find ironic in this massive and allegedly comprehensive legislation is that, as I have tried to show, the seven phenomena listed in the previous paragraph all trace to the interaction of the pair of implicit subsidies that my model highlights. These subsidies are hidden in the systems used: (1) to finance housing investments on the one hand, and (2) to finance the US financial safety net on the other. In turn, the norms that make these subsidies durable are rooted in a generalized breakdown in professional ethics that the DFA does not treat at all. The professions of government service, accounting, financial management, credit rating, mortgage banking, derivatives broker-dealer making, and government regulation all have explicit or implicit codes of practice that (wink, wink) members of the profession are expected to follow to prevent client, user, or societal abuse and to preserve the integrity of that profession.

In some countries and professions (especially medicine), violations of particular standards that impose predictable harm on other parties become a matter for law enforcement. So (I believe) it should be in finance.

\section{Focusing Only on Bank Capital is a Loser's Game}

Along with investments in political clout, bank managers can make themselves Too Big to Discipline Adequately (TBTDA) by: (1) moving highly leveraged loss exposures formally off their accounting balance-sheet, and (2) maintaining an aggressive program of mergers and acquisitions. Over time, either strategy makes a large institution ever more gigantic, ever more 
complex, and (if its managers understand the game) ever more politically influential. The profitability of undertaking these dialectical responses to banking laws and regulations is documented in Table 1 and Figure 3. To me this is evidence that the current wave of financialinstitution consolidation, and convergence is not just an efficiency-enhancing Schumpeterian long-cycle response either to past overbanking or to secularly improving technologies of communication, contracting, and record-keeping.

Any time a TBTDA organization becomes larger or extends its safety-net guarantees over a new product line, its managers are likely to see an increase in the capitalized value of the implicit government credit enhancements imbedded in their bank's capital structure (Kane, 2000; Penas and Unal, 2004; Brewer and Jagtiani, 2007). Simply put, consolidation and expansion create additional value for large institutions by reducing the contestability of the markets in which they operate. They do this in three ways: by eliminating competitors, by strengthening exit resistance, and by extending their branch networks pre-emptively into locations that might otherwise have been able to attract unrelated new entrants.

One can only wonder how much more slowly the market's appetite for CDOs and other structured securitizations would have grown if opaque off-balance-sheet vehicles such as Structured Investment Vehicles (SIVs) had not offered implicit safety-net benefits and supervisory cover to their sponsors. Controlling safety-net subsidies to risk-taking by opaque and nimble financial firms is tough enough. But it is fiendishly difficult for incentive-conflicted agency leaders to control risk-shifting at firms that capital markets perceive to be macroeconomically, politically, or administratively too difficult to close and unwind. For megabanks, the Basel approach of setting capital requirements only against what have become well-understood and easily measureable exposures is massively inadequate. 
To mimic the methods by which private counterparties keep opportunities for riskshifting under control, capital requirements have begun to introduce special surcharges designed to increase both with an institution's size and with the opacity of its deal making. But further reform legislation passed in 2018 benefits giant banks in two ways: by doing nothing new to rein in their ability to command safety-net subsidies when they are in distress and by expanding access to these subsidies for their custody activities. As always, an unreformed and elitist justice system continues to grant megabankers near-impunity for forcing the safety net - rather than their stockholders-- to finance their firms' deepest risk exposures. Managers of temporarily wellcapitalized banks routinely pressure regulators to let them use dividends or stock repurchases to distribute as much of their current earnings as they can.

Worse yet, regulators add their blessing to bankers' bullsh*t claim that this is okay because low current levels of safety-net subsidies mean that safety-net subsidies are safely under control. While it is true that the value of safety-net guarantees is relatively low at US megabanks today, this is because safety-net subsidies recede as a bank begins to build up its capital even a little (Figure 1). But the Regulatory Dialectic explains that, contrary to Adamanti and Hellwig (2013), increased capital requirements and incentive-conflicted stress tests cannot keep taxpayers' loss exposure in megabanks under control for long. Whatever the level of capital requirements, taxpayers' stake increases when and as bankers find new and better ways to hide leverage, tail risk and distress from their supervisors (Hovakimian, Kane, and Laeven, 2015).

In principle, stress tests can compensate for some of the weaknesses in the design and implementation of capital requirements (Wall, $2014 \mathrm{a}$ and b). In practice, stress tests are too narrowly focused on a few overly specific scenarios. Because neither capital requirements nor stress tests measure taxpayer risks appropriately, stress tests merely add an overlay of bullsh*t 
and stubborn belief perseverance to the supervisory process. In any case, it looks as if regulators have stopped using these tests to assess the volatility of taxpayers' stake in large banks.

Beginning this year, the Fed appears to have repurposed the tests as a way to provide supervisory cover for captured regulators to permit the megabanks to use share buybacks and dividends to pay out enough of their accumulated profits to drive their safety-net subsidies up again.

Stress-tests protocols and the enhanced resolution regimes envisioned in post-crisis reforms seek to increase the dosage and complexity of capital-requirements medicine and to prescribe it for a larger range of firms. But by themselves, tougher capital requirements are not a disincentive because they do not directly punish the architects of safety-net abuse. Instead, they challenge offenders with new constraints whose enforcement is expected to prove toothless when and if the supervisory system is once again tested by a spreading crisis.

Stress tests ask whether selected ratios can cover --not current-dated liabilities - but the degree of distress a bank's capital might be required to absorb during the next nine quarters if the bank's business and capital-distribution plans were put through a hypothetical "scenario" of adverse financial shocks and difficult macroeconomic events.

The test procedure is now called DFAST (Dodd-Frank Annual Stress Testing). The follow-on (and qualitative) interpretation and friendly re-grading of DFAST results for major US banks - which is carried out by staff at the Federal Reserve Board — shades into what is called the CCAR (Comprehensive Capital Analysis and Review).

Where's the Bullsh*t in this Instrument?

It is hard to demonstrate that this statutory expansion in post crisis control and supervision has actually helped taxpayers. The DFAST and CCAR protocols and criteria are 
improvisational and lacking in statistical rigor both in their construction and in their application. Neither the scenarios nor the prudential standards employed in the stress tests are constructed in a reproducible manner. Neither makes explicit use of probability distributions for the future prices of the assets and liabilities that define the measure of bank's capital used, even though the volatility of these prices is what is ultimately at issue.

This absence of empirical foundations gives regulators and megabank executives considerable leeway for explaining away whatever shortfalls the tests uncover. Finally, regulatory norms of rescue and helpfulness for troubled firms tempt authorities to find ways to inflate the grades and soften whatever punishments might be visited on falling firms. The traditional way to inflate a bank's examination grade is to overvalue soured assets and to undervalue liabilities whose market values might be soaring above par. A less obvious way is to invent new categories of intangible assets.

An example of how creatively accountants can create intangible assets is buried in the excuses bankers and regulators have used to downplay the significance of the low grades that the weakest megabanks achieved in the 2018 tests. The press was told that the 2018 tax cuts severely reduced regulatory "capital" at CCAR banks because it greatly lessened the value banks expect to derive from being able to write off past losses against yet-unrealized future income.

That the outcome of several banks' past stress tests turned on such a gimmick should be deeply disturbing. Authorities should have explained that the fabricated nature of this asset class had unfairly biased CCAR grades upward not only now, but in the past. Instead, authorities sought to transform this revelation into a lame excuse for granting further leniency.

Stress tests are intended to assure the public that banks have prepared themselves for the 
next crisis. It is dishonest to pretend that tax-loss carry-forwards could act as loss-absorbing capital in either a crisis or near-crisis scenario. These hypothetical assets are a counterfeit (i.e., bullsh*t) source of loss- absorbing capital because they have virtually no liquidity in a stress scenario. In a crisis, no market exists that can promptly convert future tax write-offs into cash. At an insolvent bank, except for the intangible value of safety-net support (which expands), the net worth of tax-loss carry-forwards and most other intangible positions nearly vanishes.

\section{Are the Post-Crisis Regulatory and Supervisory Systems Resilient Enough?}

Most commentators argue that US megabanks are safer now that they were in 20072008. But a more-important and unasked question is: For how long? Figure 8 tells us that the process of rebuilding leverage-driven tail risk by means of dividends and stock buybacks is already well underway.

Equally worrisome, bank information systems do not try to track taxpayers' stake in banking firms and the regulatory, supervisory and justice systems remain focused on disciplining banks, rather than bankers. As long as these conditions hold, bankers will continue to use the safety net to enrich themselves and their shareholders at our expense. 


\section{REFERENCES}

Admati, Anat, and Martin Hellwig, 2013. The Bankers' New Clothes: What's Wrong with Banking and What to Do About It?, Princeton, NJ: Princeton University Press.

Aikman, David, Jonathan Bridges, Anil Kashyap, and Caspar Siegert, 2018. "Would Macroprudential Regulations Have Prevented the Last Crisis?," presented at an NBER conference (July 11).

Beim, David, 2001. “What Triggered a Banking Crisis?,” Columbia University Working Paper (June).

Brewer, Elijah and Jagtiani, Julapa, 2007. "How Much Would Banks Be Willing to Pay to Become 'Too-Big-to-Fail' and to Capture Other Benefits," Working Paper, Federal Reserve Bank of Philadelphia (July).

Caprio, Gerard, and Daniela Klingebiel, 1999. "Episodes of Systemic and Borderline Financial Crises," Working Paper and Database, World Bank website, periodically updated.

Demirgüç-Kunt, Asl1, Edward J. Kane, and Luc Laeven, 2016. "Deposit Insurance Database," Journal of Financial Stability, 20, 155-183.

Demirgüç-Kunt, Asl1, and Harry Huizenga, 2010. “Are Banks Too Big To Fail or Too Big To Save? International Evidence from Equity Prices and CDS Spreads,” World Bank Working Paper (January).

Ferguson, Thomas and Robert Johnson, 2009. 'Too Big to Bail: The 'Paulson Put,' Presidential Politics, and the Global Financial Meltdown," Parts 1 and 2, International Journal of Political Economy, 38, nos. 1 (pp. 3-34) and 2 (pp. 5-45). 
, Paul Jorgenson, and Jie Chen, 2017. "Fifty Shades of Green: High Finance, Political Money, and the US Congress," New York: Roosevelt Institute Working Paper (May). http://rooseveltinstitute.org/fifty-shades-green/

Folkerts-Landeau, David, 2018. "Deutsche Bank Chief Economist Criticizes the Josef Ackermann Era," Handelsblatt (May 21), www.handelsblatt.com.

Frankfurt, Harry G., 2005. On Bullshit. Princeton, NJ: Princeton University Press.

Hock-Smit, Marja C., and Douglas B. Diamond, 2003. "Subsidies for Housing Finance: Based on a Report Prepared for the World Bank Seminar on Housing Finance in Emerging Markets," Housing Finance International (March), 3-13.

Hoffman, Liz, and LaLita Clozel, 2018. "Morgan, Goldman Got Help from Fed on Tests," Wall Street Journal 272 (July 3), A1-A2.

Honohan, Patrick, and Daniela Klingebiel, 2000. "Controlling the Fiscal Costs of Banking Crises,” World Bank Policy Research Working Paper No. 2441 (September).

Hovakimian, Armen, Edward J. Kane, and Luc Laeven, 2012, 2015, “Tracking Variation in Systemic Risk at US Banks During 1974-2013,” (unpublished).

Kane, Edward J., 1989. "Changing Incentives Facing Financial-Services Regulators," Journal of Financial Services Research, 2 (August), 265-274.

, 1996a. "De Jure Interstate Banking: Why Only Now?," Journal of Money, Credit, and Banking, 28 (May 1996), pp. 141-161.

, 1996b. “The Increasing Futility of Restricting Bank Participation in Insurance Activities," in Anthony Saunders and Ingo Walters (ed.), Financial System Design: 
Universal Banking Considered, Homewood, IL: Irwin Professional Publishers, 338354.

, 2000. "The Dialectical Role of Information and Disinformation in RegulationInduced Banking Crises,” Pacific Basin Finance Journal 8, 285-308.

, 2002. "Using Deferred Compensation to Strengthen the Ethics of Financial

Regulation," Journal of Banking and Finance, 26, 1919-1933.

Kane, Edward J., and Daniela Klingebiel, 2004. "Alternatives to Blanket Guarantees for Containing a Systemic Crisis," Journal of Financial Stability, 1 (1), 671-701.

Kline, Alan, 2018. "Small Banks Will Get Regulatory Relief: Do They Deserve More?," Bankshot, American Banker, https://www.americanbanker.com/opinion/smallbanks-will-get-reg-relief-do-they-deserve-more.

Laeven, Luc, and Fabian Valencia, 2012. "Systemic Banking Crises: An Update," Washington, DC: International Monetary Fund WP/12/163 (June).

Onaran, Yalman, 2018. “Can We Survive the Next Crisis?,” Bloomberg (September 10). https://www.bloomberg.com/graphics/2018-lehman-anniversary/.

Penas, Maria and Haluk Unal, 2004. "Gains in Bank Mergers: Evidence from the Bond markets," Journal of Financial Economics 74 (1): 149-179.

Schein, Edgar H., 2010. Organizational Culture and Leadership, 4th Edition. San Francisco: Josey-Bass (a Wiley Imprint).

Taleb, Nassim N., 2018. Skin in the Game: Hidden Asymmetries in Daily Life. New York: Random House.

Wall, Larry D., 2014a. "The Adoption of Stress Testing: Why the Basel Capital Measures Were 
Not Enough," Journal of Banking Regulation, 15 (3/4), 266-276c.

, 2014b. "Measuring Capital Adequacy: Supervisory Stress Tests in a Basel World," The Journal of Financial Perspectives, 2 (no. 1), (March), 85-94.

, 2018. “Is Stricter Regulation of Incentive Compensation the Missing Piece?” Atlanta:

Federal Reserve Bank of Atlanta (April 9). 
TABLE 1

Table: Assets and Profits Since 2008 of the Five Biggest US Financial Corporations

\begin{tabular}{|c|c|c|c|}
\hline Name & Headquarters & Assets & Profits Since 2008 \\
\hline JPMorgan Chase & New York, NY & $\$ 2,609,785,000,000$ & $\$ 188,264,000,000$ \\
\hline Bank of America & Charlotte, NC & $\$ 2,328,754,000,000$ & $\$ 81,908,000,000$ \\
\hline Citigroup & New York, NY & $\$ 1,922,104,000,000$ & $\$ 68,810,000,000$ \\
\hline Wells Fargo & San Francisco, CA & $\$ 1,915,388,000,000$ & $\$ 174,008,000,000$ \\
\hline Goldman Sachs & New York, NY & $\$ 973,546,000,000$ & $\$ 70,262,000,000$ \\
\hline TOTAL & - & $\$ 9,749,577,000,000$ & $\$ 583,252,000,000$ \\
\hline
\end{tabular}

Source: Commondreams.org/news/2018/09/11 
TABLE 2

DIALECTICS OF A SUBSIDY-INDUCED CRISIS

THESIS: UNSUSTAINABLE POLICY MIX

- Expansionary Monetary Policy and Loss-Causing Credit-Allocation Scheme ("politically sabotaged loans") vs. Adverse Effects of De-supervising Risks by Providing Growing Safety-Net Support for Loss-Making Mortgage Lenders

\begin{abstract}
ANTITHESIS: SKEPTICAL INVESTORS AND DEPOSITORS ARE EVENTUALLY GOING TO TEST GOVERNMENTS' ABILITY TO MANAGE THE EXPANDING COSTS OF NATIONAL SAFETY NETS
\end{abstract}

- In the Beginnings of a Financial Crisis, Market Tests Consist of Silent Runs by Large Creditors (Symptomized by a Generalized Flight to Asset Quality and Simplicity)

- Supervisory Forbearance Expands and the Probability of a Deepening Crisis Rises, As Long As Authorities Refuse To Contain The Damage And Continue To Help Zombie Institutions To Stay In Play

SYNTHESIS: BREAKDOWN OCCURS AND AUTHORITIES HAVE TO QUELL MARKET DOUBTS ABOUT THEIR WILLINGNESS OR ABILITY TO SUSTAIN THE CONTRADICTORY POLICY MIX.

- Credit-allocation scheme unravels at least in part

- Size and Incidence of the bill for sustaining decapitalized institutions becomes more and more manifest

- Taxpayers beg for reform 
TABLE 3

\section{DETAILED STAGES OF A SUBSIDY-INDUCED BANKING CRISIS}

1. Rent-Seeking Generates Aggressive Loss Exposures at Highly Leveraged Institutions

- Pursuit of Safety-Net Subsidies Tied to Government-promoted Forms of Lending

- Pursuit of Safety-Net Subsidies Tied to Other Kinds of Leveraged Risk-Taking

2. Adverse Events and Industry Problems Upset Financial Markets

- Banks and Regulators Keep Losses from Registering on Anyone's Books by Accounting Trickery and Cover-up

- Large-Denomination Creditors Test the Safety Net Via a Silent Run

- Fragility of System Rises as Good and Even Questionable Assets are Collateralized and Endgame Incentives Induce Go-For-Broke Gambling at Zombie Institutions

- Threat of Shortages in Safety-Net Funding Rises Over Time

3. Supplementation of Traditional Safety-Net Support Mechanisms

- Loans from Central-Bank Discount Window Carry an Ever Larger Load

- Inventive Accounting Loopholes and Forms of Public Credit Expand

4. Recapitalization of Troubled Firms and Safety-Net Institutions

A. Stopgap Partial Recapitalizations: Half-Measures Move the Financial Sector Back into Stage Two of Three of the Cycle

B. Transformation of Private Losses into Explicit Taxpayer Obligations or Explicit Nationalization of Zombie Firms

5. Formal Clean-Up of the Mess

- Blame Heaped Politically on Designated Scapegoats

- Credible Safety-Net Reforms are Adopted Under Strongly Adverse Lobbying Pressure

- Re-privatization of Zombie Institutions 
TABLE 4

ONE-YEAR KAMAKURA DEFAULT PROBABILITIES FOR LARGE EUROPEAN BANKS ON MY WATCHLIST

\begin{tabular}{|l|c|c|c|}
\hline \multicolumn{1}{|c|}{ Bank Name } & KDP Model & Term & Actual KDP(\%) \\
\hline ATTICA BANK SA & JC6 & 1 Year & 13.207100 \\
\hline BANCO BPM SPA & JC6 & 1 Year & 5.963000 \\
\hline BANCO SANTANDER SA & JC6 & 1 Year & 2.646400 \\
\hline BANK OF IRELAND GROUP PLC & JC6 & 1 Year & 1.433900 \\
\hline BBVA & JC6 & 1 Year & 3.924700 \\
\hline CREDIT SUISSE GROUP & JC6 & 1 Year & 3.423600 \\
\hline DEUTSCHE BANK AG & JC6 & 1 Year & 3.526800 \\
\hline LLOYDS BANKING GROUP PLC & JC6 & 1 Year & 2.510900 \\
\hline ROYAL BANK OF SCOTLAND GROUP & JC6 & 1 Year & 1.073100 \\
\hline UNICREDIT SPA & JC6 & 1 Year & 2.779600 \\
\hline
\end{tabular}




\section{FIGURE 1}

\section{DESPITE THE BULLSH*T ADOPTION OF NO-BAILOUT POLICIES BY THE EU, DEUTSCHE BANK AG HAS REMAINED A ZOMBIE, EVIDENCING SAFETY-NET SUBSIDIES MOST OF THE TIME}

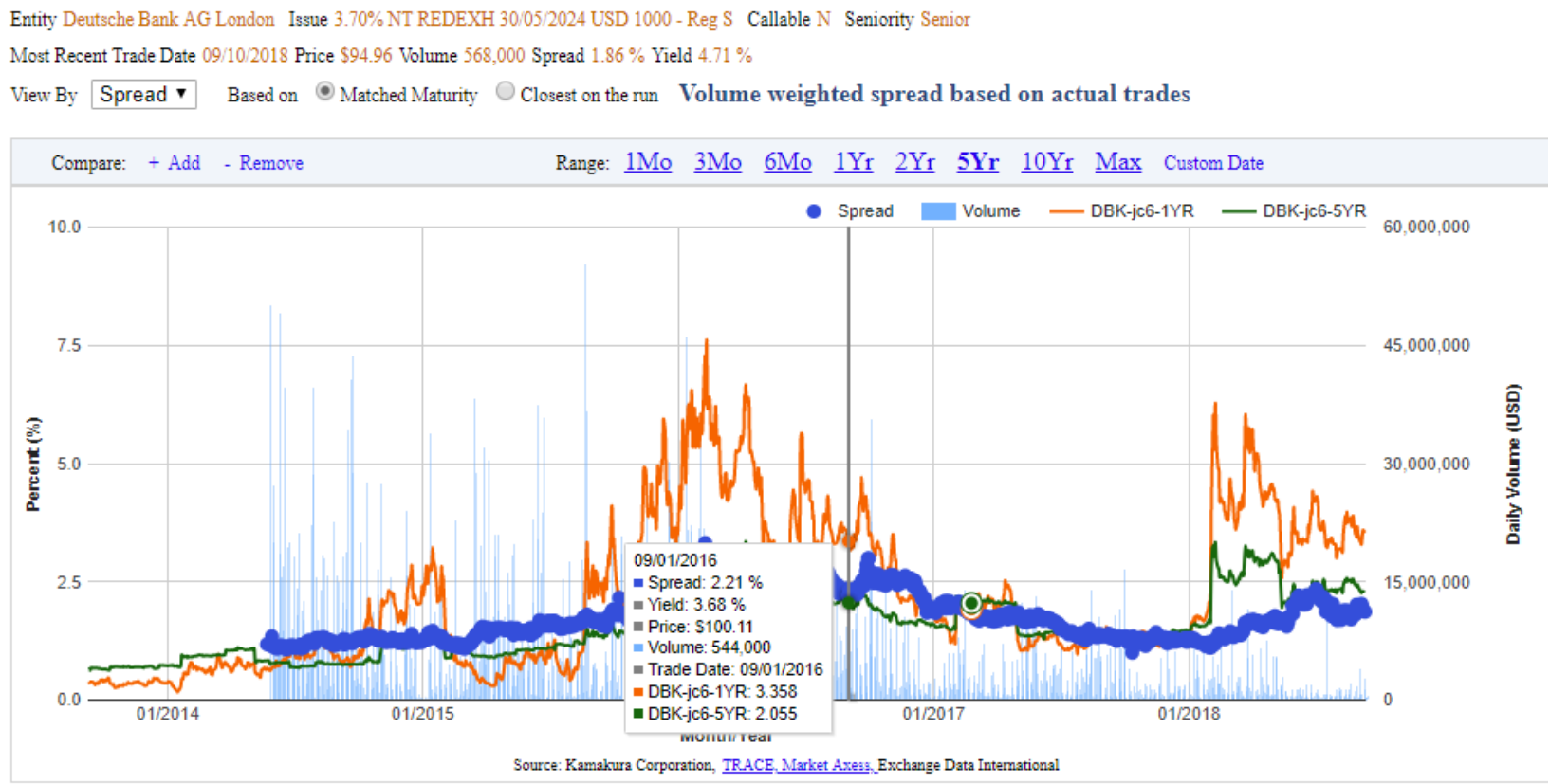

Copyright $\odot$ Kamakura Corporation, 2002-2018

Source: KRIS website. I am deeply grateful to Donald van Deventer for allowing me to use his data.

How to read this graph: If this or any other Deutsche Bank bond were trading solely on the bank's own credit, its interest spread would stay above its one-year and five-year probability of default. Hence, observing KRIS estimates of the probability of default (kdp) well in excess of the interest spread indicates that DBK is a zombie and the distance provides a conservative measure of its zombieness.

The Jarrow-Chava logistic model that generated the default probabilities is well documented and (despite its reproducibility) outperforms the ratings constructed by major credit organizations (as Figure 2 shows). To obtain regular access to the model's predictions, more than a few banking agencies around the world are paid subscribers to Kamakura Risk Information Services. 
FIGURE 2

EVIDENCE THAT KAMAKURA CORPORATION'S ESTIMATES OF DEFAULT PREMIA DO A BETTER JOB OF VALUING CORPORATE BONDS THAN TRADITIONAL CREDIT RATINGS

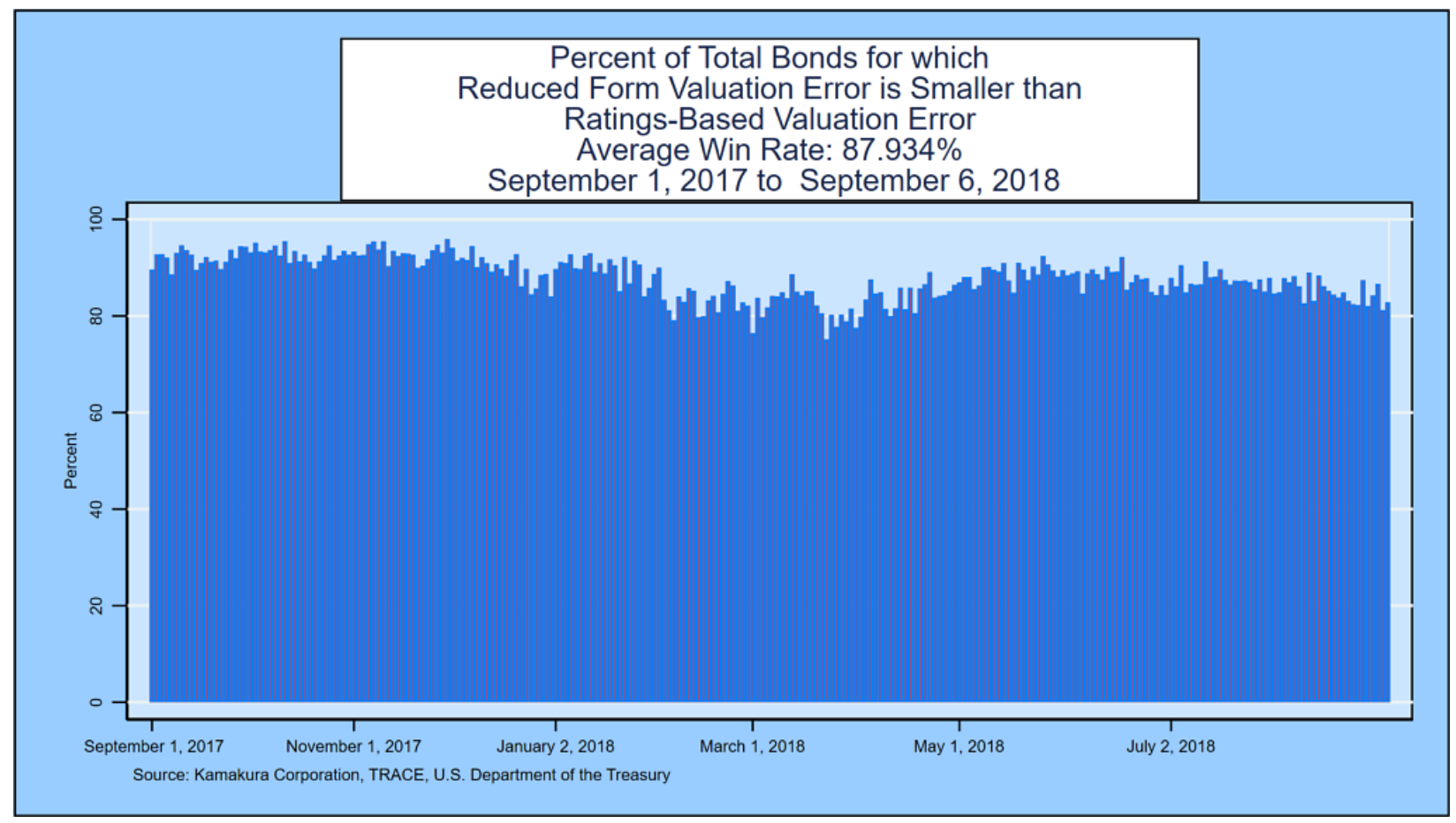


FIGURE 3

\section{POST-CRISIS STOCK PERFORMANCE OF THE TOP FIVE US MEGABANKS}

\section{US banks' performance}

Share prices (rebased)

- JPMorgan

- Goldman Sachs

- Morgan Stanley

- Bank of America

- Citigroup
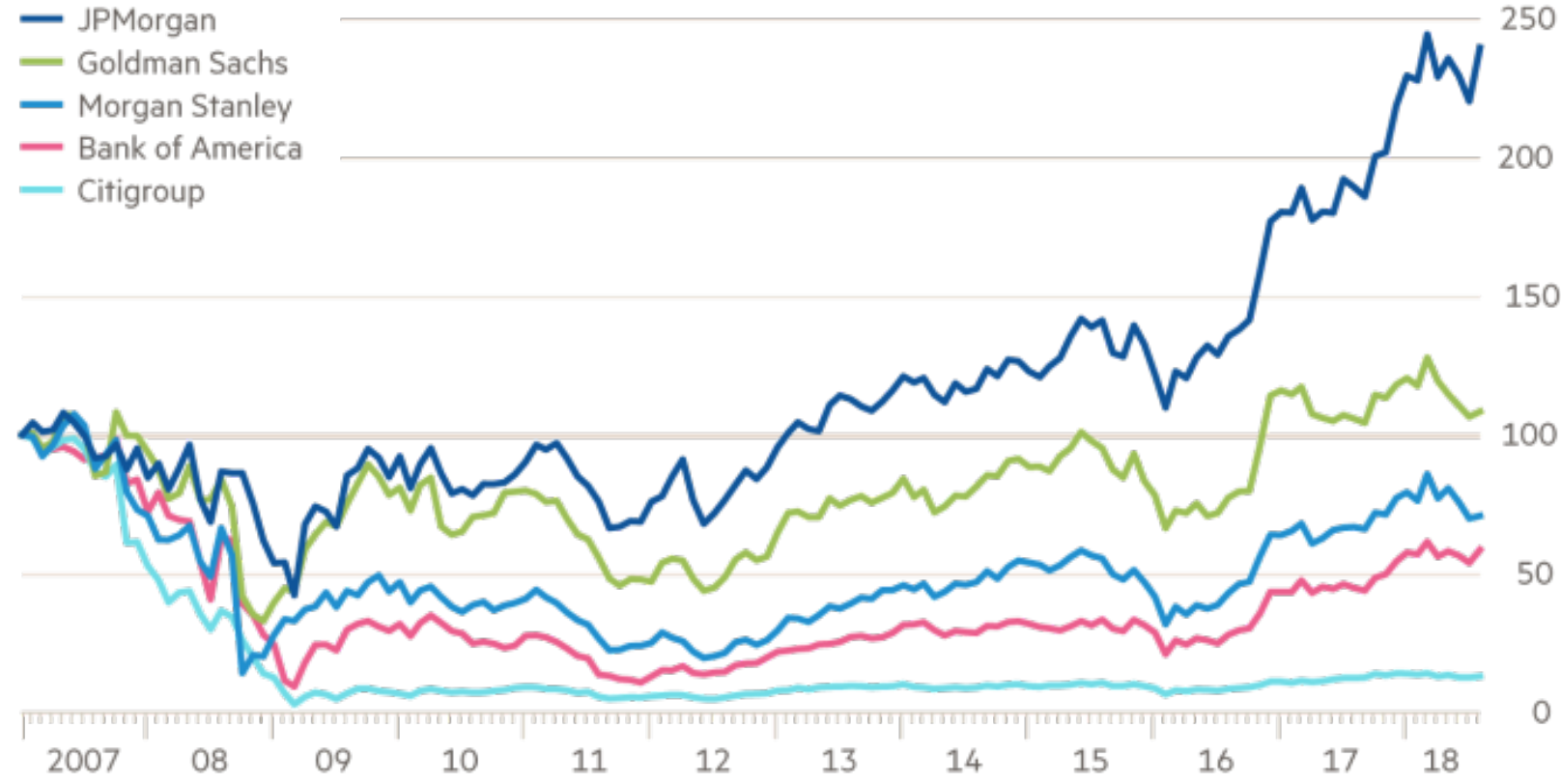

Source: Thomson Reuters Datastream (c) $F T$ 
FIGURE 5

MEAN RATIO OF ESTIMATED EQUITY CAPITAL TO ASSETS FOR THE HOVAKIMIAN, KANE AND LAEVEN SAMPLE OF U.S. BANK HOLDING COMPANIES, 1974-2010 (QUARTER BY QUARTER IN PERCENT)

\section{Estimated Ratio of Equity Capital to Assets at Sampled Institutions}

25

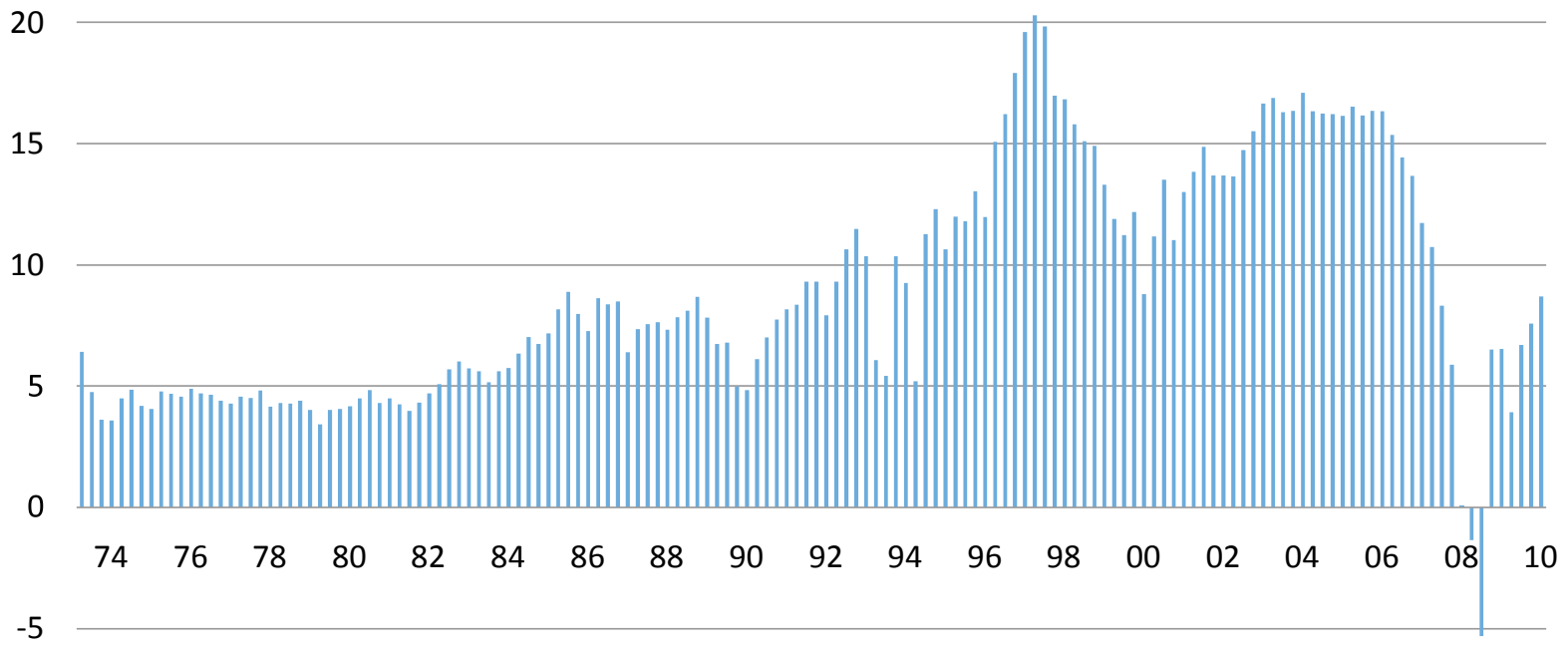

$-10$

Sources: Hovakimian, Kane and Laeven (2012). 


\section{FIGURE 6}

STRESS-TESTS RESULTS FOR CCAR MEGABANKS, 2012-2017

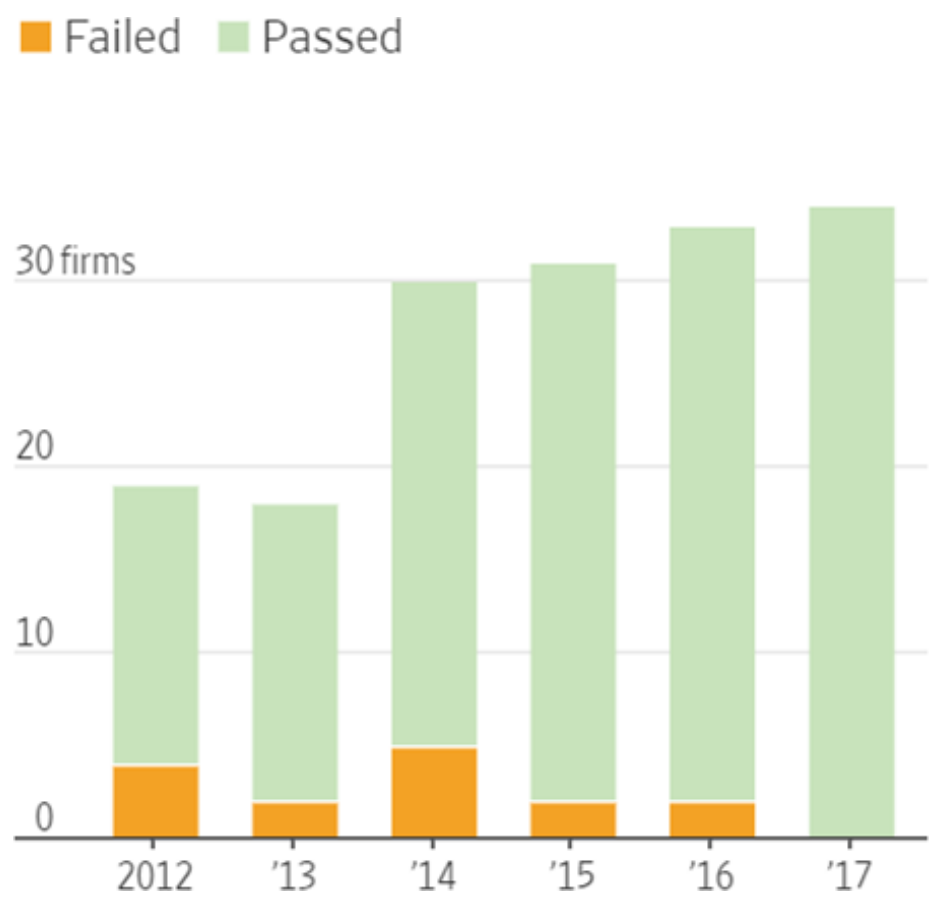

Source: Graphic from The American Banker based on Federal Reserve data 


\section{FIGURE 7}

\section{CCAR RESULTS FOR ALL 35 BANKS WITH CONSOLIDATED ASSETS ABOVE THE STATUTORY \$100 BILLION THRESHOLD}

Several megabanks that cleared the quantitative portion of the Fed's CCAR stress tests missed or were uncomfortably close to the Fed's minimum threshold

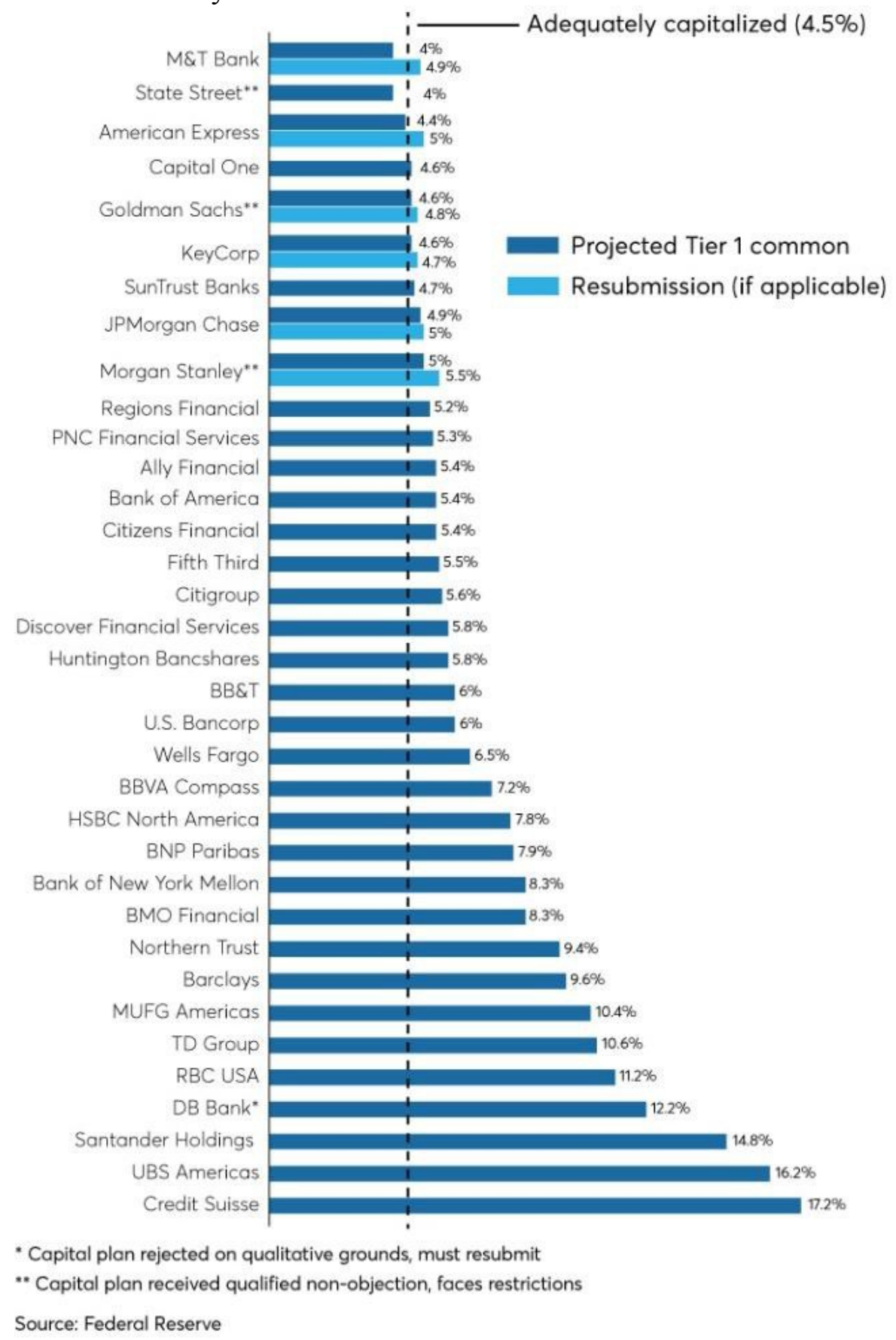


FIGURE 8

2018 POST-CCAR SHAREHOLDER PAYOUTS FORECASTED FOR SELECTED US MEGABANKS

\section{Shareholder payouts on the rise}

Forecast gross dividends and buybacks as a percentage of profits

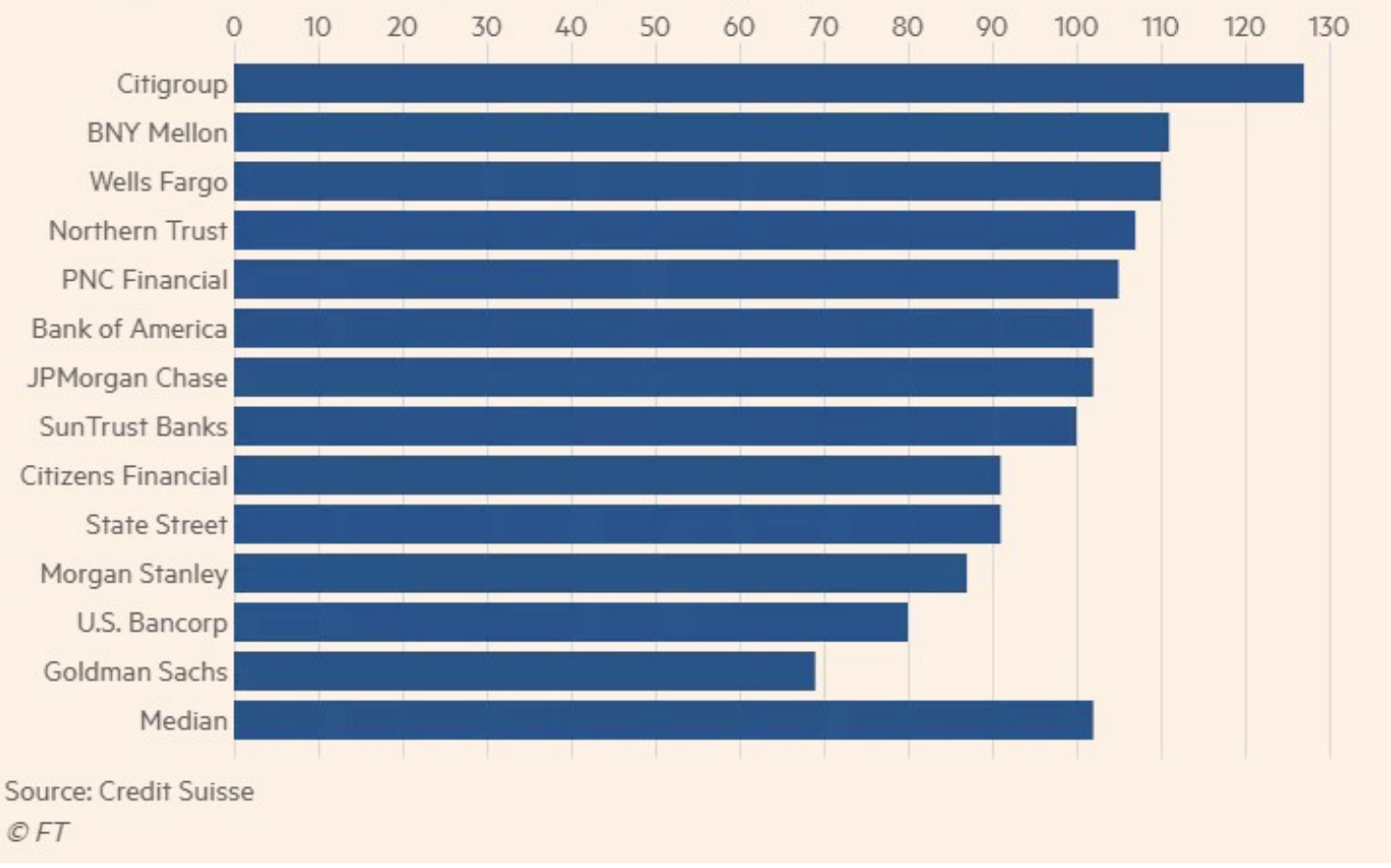




\section{APPENDIX: MODELING SUPERVISORY FORBEARANCE AS A CRISIS-DELAYING MARKOV PROCESS}

It is instructive to focus on the occurrence or nonoccurrence of a crisis-triggering creditor run and to model continuations and observable breakdowns in a banking system's (possibly weakening) funding arrangements as two states of an evolutionary Markov process. Period by period, the probability that a banking system stays in a manageable state is $\mathbf{p}$ and the probability it passes into an actual crisis is (1-p). Though (1-p) is very small on any given day, the cumulative probability of transitioning to a systemic industry breakdown during a time-buying top regulator's next $\mathbf{N}$ days in office is (1-p) ${ }^{\mathbf{N}}$ if $\mathbf{p}$ is unlikely to worsen or improve over time. Of course, if adverse information starts to leak out, the value of $\mathbf{p}$ is apt to decrease and to decrease all the more rapidly when the extent of hidden insolvencies and the perceived fragility $(\mathbf{F})$ of the implicit support system are both high. The credibility of the implicit guarantees that constitute the support system helps to hide megabank insolvencies by reducing the likelihood of creditor runs that might otherwise test the system and push it into crisis.

It is convenient to represent the unmeasured value of various governments' joint guarantees as $\mathbf{G}$ to banks and the cumulative size of taxpayers' hidden responsibility for supporting the liabilities of troubled institutions as $\mathbf{T}$. (T may be identical or nearly equal to $\mathbf{G}$ in many cases.) Other things equal, $\mathbf{T}$ and $\mathbf{G}$ also decrease with the fragility (F) of the support system, since a breakdown of the system could transfer some of the losses for which taxpayers had been on the hook to bank creditors.

The important thing is that whenever the fragility of outside support increases, so does (1-p). During the early stages of an incipient crisis, increments in the probability $\mathbf{p}$ of remaining in the non-crisis state also depend on the informativeness (A) of the accounting principles under which financial institutions and safety-net officials report losses and loss exposures. This leads 
to a simple equation for the evolution of the transition probability $\mathbf{P}_{\mathbf{t}}$. On any particular day $\mathbf{t}$ :

$$
\mathbf{p}_{t}=\mathbf{p}\left[\mathbf{G}_{t}, \mathbf{T}_{\mathrm{t}}, \mathbf{F}_{\mathrm{t}} ; \mathbf{A}_{\mathrm{t}}\right]
$$

In (1), except for $\mathbf{A}$, the partial derivatives of the drivers of $\mathbf{p}$ are negative. During the early stages of a threatened run, financial institutions are tempted to seek "accounting relief" that their regulators may feel all too willing to provide. However, once market participants begin to recognize partial recapitalizations and accounting cover-ups as half-measures, efforts to weaken $\mathbf{A}$ are seen to compound the problem and improvements in $\mathbf{A}$ become a candidate for inclusion in the crisis-resolution process. Of course, the eventuality of moving back out of the crisis state into the manageable, but generally still-fragile state has a probability $\mathbf{q}$ and an evolutionary process of its own. The essence of a crisis is a scrambly effort by those contractually responsible for bank losses to find ways to shift their loss exposures onto other parties. In this process, the amount and character of explicit creditor, manager, and stockholder bailouts feature prominently. Ideally, crisis managers should seek to get back to the manageable state quickly, work hard afterwards to hold individual bankers accountable for acts of reckless behavior, and try to drive $\mathbf{p}$ as low as they can. Taxpayers need to ask themselves what it is about the politics of crisis management that makes this impossible. 